\title{
Law and theory
}

\section{Lawyer-client confidences and privilege: USA and UK compared by Victor Tunkel}

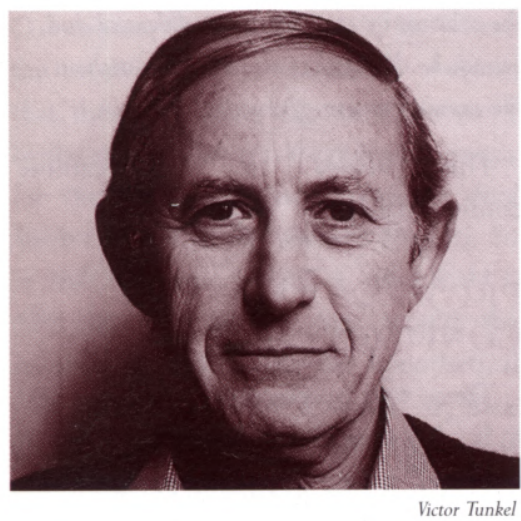

The recent surge of legal happenings in and around the White House leads one here in England to reflect on what would be our own law's equivalents or responses. After all, impeachment was an English legal antique when the US constitution took in a colonial reproduction - the grand jury, another English export, we dumped long ago. Good riddance to both. But other aspects of the Clinton affair raise legal issues, in particular about lawyer-client confidences, which remain unsettled on both sides of the Atlantic.

\section{LAWYER-CLIENT PRIVILEGE AFTER DEATH}

In 1993, seven members of the White House travel office staff were peremptorily dismissed. A congressional investigation was launched into these dismissals. Vince Foster, a member of the White House staff presumably concerned in the affair, spent two hours with his lawyer, James Hamilton, at which interview Hamilton took hand-written notes. Nine days later Foster committed suicide. In December 1995, the Independent Counsel, Mr Kenneth Starr, sought to subpoena Hamilton and his firm, Swidler \& Berlin, to provide his notes for the federal grand jury inquiring into the affair. Hamilton claimed privilege. The district court upheld his claim. The Court of Appeals reversed this, on the ground that once a client is dead the claim to privilege must be balanced against the importance of disclosure for the needs of a subsequent criminal case. But the Supreme Court upheld the claim by six votes to three (Swidler \& Berlin v US (1998) $118 \mathrm{~S} \mathrm{Ct}$ 2081). They said that the justification for the privilege is the willingness of the client to confide in his lawyer in the knowledge that his confidences will be protected; a willingness which might be diminished if the client knew that posthumous revelation was possible. The only exception acknowledged by the court was the 'testamentary exception' where a lawyer might be required to reveal a deceased client's communications so as to settle any disputes between beneficiaries.

Pausing to look at English law in these matters, it seems well settled. The privilege certainly survives the death of the client (Bullivant v A-G [1901] AC 196, 206) as does the power to waive it ( $R e$ Molloy [1997] 2 Cr App R. 283). The 'testamentary exception' also exists (see, e.g. Re Williams [1985] 1 All ER 964, where it was taken for granted that a letter sent by the testatrix to her lawyers was properly revealed to assist in construing her home-made will). However, we would define it more widely. From Conlon v Conlans Ltd [1952] 2 All ER 462, a commercial case, it seems that a court may infer that a client's communication to his lawyer was intended to be passed on, in the event of certain subsequent circumstances, and will so order. And indeed, this generalised approach seems to be gaining professional acceptance in the USA:

'A lawyer shall not reveal information relating to representation of a client ... except for disclosures that are impliedly authorized in order to carry out the representation ...' (Rule 1.6 of American Bar Association (ABA) Model Rules of Professional Conduct 1996)

\section{DURABILITY OF THE PRIVILEGE}

If death does not terminate the privilege, what does? The traditional answer of our courts is 'once privileged always privileged'. So in Crescent Farm v
Sterling [1972] Ch 553, a successor in title was held to be entitled to withhold a document containing the legal advice given to his predecessor and passed on to the successor. The interval of years was not very long but could have been generations, presumably. But would our courts countenance a balancing exception of the sort argued for in the Supreme Court case? Supposing it is very many years afterwards and supposing there is someone representing the longdead client and purporting to invoke the privilege, may a court take into account the evaporation of the rationale, the time elapsed, the public or historic interest, the lack of any adverse effect on any individual, the availability of some of the information in the public domain, and such similar factors?

To all such arguments the House of Lords have given a resounding 'no'. In $R$ v Derby Magistrates ex parte B [1995] 4 All ER 526, Lord Taylor CJ said:

\section{... if a balancing exercise was ever required \\ it was performed once and for all in the sixteenth century. No exception should be allowed to the absolute nature of legal professional privilege.'}

The dire effect was to prevent an accused on trial for murder establishing his innocence. The decision has been criticised: for one thing, there are other exceptions already; and the Lords relied on purely civil precedents. But the law must be taken as settled, subject to a small window left open by Lord Nicholls's obiter dictum in the case: that where a client no longer had any interest in maintaining his privilege, it might be treated as spent.

\section{PRIVILEGE FOR SALARIED LAWYERS}

Back to the White House. How would our courts have responded to the type of claim for privilege made by Bruce Lindsey? Lindsey, a lawyer and one of the President's closest advisers and confidants, refused to answer questions before the grand jury as to what the 
President had said to him by way of response to Kathleen Willey's accusations of Oval Office gropings. On appeal, Lindsey was ordered by the Court of Appeals to answer. To the English reader this may at first seem puzzling. The explanation is that privilege never arose because Lindsey's relationship with Clinton was that of a governmentemployed lawyer advising a government official. The American Law Institute's Restatement of the Law Governing Lawyers (1996), para. 124d, deals with the matter:

'Government lawyers may be prohibited from the private practice of law or accepting a matter adverse to the government. Thus the fact that the common employer of both lawyer and officer is a government agency may affect the reasonableness of the officer's claim of expectation that the lawyer could function as personal counsel to the officer.'

So the test appears to be twofold: whether the President expected Lindsey, as a government employee, to be able to safeguard his disclosures; and, if he did so expect, whether this expectation was reasonable. If this problem seems not to have arisen in England, it may be because of the cloak of Crown privilege, latterly public interest immunity, thrown over virtually all communications at governmental level and almost impenetrable until recently. However it could arise here within a nongovernmental organisation, in which case it might seem unfair if privilege were denied. An employee of a company may well consult privately one of his colleagues, who happens to be a lawyer employed by the company, for personal advice unconnected with their employment. No fee is asked or paid. Would both of them be compellable to disclose to a court what passed between them? Does it turn on whether the lawyer's employment allows, or precludes, his advising outside his work? If so, is he bound to inform his quasiclient before too much is said? For most purposes, courts both here and in the USA treat employed lawyers as independent professionals even though advising their own firm or company. (See Upjohn v US (1981) 449 US 383,391; and Alfred Crompton v Customs \& Excise [1974] AC 405, in which case the clients and the lawyers were both part of the same government department.) The privileged status is of course for the benefit of the employer as against its opponents. But by parity of reasoning the same status could be claimed where an employee, litigating in person on a purely private matter, sought to withhold from disclosure communications to or from his employed lawyer-colleague, purporting to act as an independent professional.

\section{THE PROFESSIONAL CODES}

On this, the American Restatement para. 212 perhaps concedes a little:

'A lawyer may not represent both an organization and its director, officer, employee, shareholder, etc., if there is a substantial risk that the lawyer's representation of either would be materially and adversely affected by the lawyer's duty to the other.'

This could mean merely that a lawyer in private practice must not act for both of two clients in potential conflict with each other. Could it also mean in the case of an employed lawyer that if the representation is wholly outside any context or concern of the employer, the off-duty lawyer may take it on and thereby attract privilege? From personal experience it is not uncommon for university staff to seek legal advice from their law-teacher colleagues. So long as the matter has nothing to do with their university employment, it should be recognised as privileged. The Law Society's Employed Solicitors Code 1990 (1997 revision) applicable to solicitors who are employed by non-solicitors, states that, subject to there being no conflict of interest or breach of the usual professional standards, and to the question of insurance:

'An employed solicitor may act for (a) a fellow-employee; (b) a director [etc.] of the solicitor's employer ...' (para. 2)

As to government-employed lawyers, para. 9 of the Code states that they:

\section{may in carrying out the functions of} the employer give legal advice to other persons and in the case of statutory functions may act generally for such persons.'

On a fair reading of this, it seems specific to and even enlarging their employed functions, but in no way detracting from the permissive para 2. Yet in their commentary, the learned editors of Cordery on Solicitors paraphrase para. 9 ambiguously, stating that they: may only give advice to other persons in the course of carrying out the functions of the employer ...' [emphasis added]

The matter remains to be tested. What the Code makes quite clear is in para. 1(e):

'Where an employed solicitor is acting for a person other than that employer in accordance with this Code, any information disclosed to the solicitor by the client is confidential and cannot be disclosed to the employer without the express consent of the client.'

This brings us to examine confidentiality.

\section{PRIVILEGE AND CONFIDENTIALITY}

These two overlapping concepts need to be distinguished. Privilege (in England confined to lawyer and client communications) confers the common law right to refuse to answer questions in court, or to produce documents, concerned with seeking or giving legal advice, without being guilty of contempt; and also to prevent one's lawyer answering. Confidentiality, supported by equity, is primarily a professional-ethical duty on the lawyer not to reveal his client's confidences. It is more general in that it covers all manner of client matters, and every possible outlet of leakage.

\section{CONFIDENTIALITY AS A BACK-UP}

In the USA in recent years, the protection surrounding a privileged relationship has been extended by Federal Rules and State Codes so as to prevent disclosure by unauthorised third parties, whether eavesdroppers, interceptors, or others, who by their own initiative have wrongfully acquired privileged information. In this country we have not yet taken this step. Once a privileged communication gets into the hands or hearing of a third party, the privilege is pro tanto destroyed (see, e.g. Calcraft ${ }_{v}$ Guest [1898] 1 QB 759; $R$ v Tompkins (1978) 67 Cr App R 181). However in the all too frequent occurrence where careless lawyers allow privileged documents to be seen by opposing parties, it seems that our two jurisdictions have much the same approach - which here, at least, is to invoke the residual confidentiality remedy. A lawyer who unexpectedly receives materials which appear confidential and not intended for him is 
supposed to not read them and to inform the sending lawyer (see, e.g. Berg Electronics v Molex Inc (1995) 875 F Supp 61; English \& American Insurance v Herbert Smith [1988] FSR 232). Where the receiving lawyer is not aware of the mistake until after reading the docunents there is no breach of ethics, according the DC Bar Legal Ethics Committee, Opinion 256 (1995). Where the receiving lawyer reasonably assumes that there has been voluntary discovery by the sending lawyer, there is no remedy for the negligent sender (Pizzey $v$ Ford Motor Co (1993), The Times, 8 March). So in IBM ${ }_{v}$ Phoenix [1995] 1 All ER 413, 424 the test applied was: would the mistake be obvious to the hypothetical reasonable solicitor? If it would be, then an injunction may be granted to prevent use of the documents or information.

\section{THE DURABILITY OF CONFIDENTIALITY}

In the Swidler case (cited above), the Supreme Court had to decide only the limited question of whether lawyer-client privilege survives the client's death, not the wider one of how long it may last. As to this, various American authorities have suggested that it should be capable of expiration by, for example, effluxion of time, or by the winding-up of a deceased client's estate. Since in England the privilege seems to be everlasting, such innovations in US law would pass us by. But they could be helpful by analogy in suggesting limits on the confidentiality aspect. Much depends on the comparative effect of the two duties. In privilege the client is saying 'even in defiance of a court I can prevent my lawyer from answering'. Can he add, as to confidentiality, "how much more so can I prevent him from disclosing to all and sundry'? ('And if $I$, then also my successors?') Or is the duty of confidentiality innately more vague, weak and transitory?

It is not difficult to find dicta stating that it, too, is permanent and absolute. Thus in US $v$ Standard Oil Co ((1955) 136 F Supp 345, 355):

'The confidences communicated by a client to his attorney must remain inviolate for all time if the public is to have reverence for the law and confidence in its guardian ... The client must be secure in the belief that the lawyer will be forever barred from disclosing confidences reposed in him.'
In the recent 'Chinese walls' case, Bolkiah $v$ KPMG [1999] 2 WLR 215, $225 \mathrm{G}$, Lord Millett reasserted the lawyer's duty in the strongest terms:

'Whether founded on contract or equity, the duty to preserve confidentiality is unqualified. It is a duty to keep the information confidential, not merely to take all reasonable steps to do so. The former client ... is entitled to prevent his former solicitor from exposing him to any avoidable risk; and this includes the increased risk of the use of the information to his prejudice...'

The particular prejudice in both cases was the prospect of the lawyer's making use of information acquired while acting for a client when subsequently acting for a new client adversely to the former client. But the strictures may hold good for all situations which are potentially prejudicial.

\section{DISPOSAL OF HISTORIC FILES}

Suppose an old firm of lawyers, clearing out their basement, found dusty files concerning some major public figure for whom they had acted in the dim past. Would they be safe to deposit these with an archive? If a putative descendant of the client were to appear and to demand non-disclosure, claiming perhaps to protect the reputation of the longdeparted, what would be the lawyers' proper course? Should they shred, or hand over to the descendant, or apply to the court to be released from their duty, or return the files to their oubliette, or deposit and be damned? And if the last, what should be the response of the depositees to the claims of the descendant?

The final draft (1996) of the American Restatement: The Law Governing Lawyers states:

'The duty of confidentiality continues so long as the lawyer possesses confidential client information. It extends beyond the end of representation and beyond the death of the client.'

It goes on to say that the lawyer must provide for 'the return, destruction or continued safekeeping of client files' in the event of the lawyer ceasing for whatever reason to practise. It does not advise further on which of these actions should apply in which circumstances; nor does it consider the conservation of historically important materials.
In England, the Law Society's Guide to Professional Conduct of Solicitors (7th edn 1996) contains guidelines. The lawyer is to retain all files for at least six years because of the possibility of claims. After that the position may be reviewed. If there are documents belonging to the client, these must be offered back, or destroyed with permission. But the Law Society takes the view that lawyers' files, including original letters from clients, are the property of the lawyer. No authority is stated but this may be in reliance on $R e$ Thomson (1855) 20 Beav 545 (obiter, Romilly, R) and Re Wheatcroft (1877) 6 Ch D 97 (ratio, Jessel, MR). That being so, they recommend that those which (in the estimation of the lawyer) are of historical value may be deposited with the county archivist. What restrictions may be imposed on the archive as to access are not stated, save for the possibility of a subsequent claim of ownership. Those files which the solicitors consider to have no such value may be shredded.

\section{NEED TO PROTECT DOCUMENTS \& LAWYERS}

This sounds like 'if in doubt, shred'. Destruction is of course the ultimate guarantee of non-disclosure. But much valuable material may be lost in this way. One would think that an archivist is a better judge of these things than a lawyer, save perhaps where it is a leading case with its background, rather than major public events or personages, that the documents would reveal. To offer an extreme example, some years ago I saw at auction a large box containing all the court documents, pleadings, correspondence, counsel's opinion, etc., in the case of Ashford $v$ Thornton (1819) (the last case in which the right to trial by battle was claimed). These must have come ultimately from some lawyer's custody. There must be many similar collections from venerable causes célèbres in lawyers' hands, of great value to legal and social historians. Yet in our unsettled state of law, depositing these with an archive may itself amount to a breach of confidentiality, inclining the solicitors to destroy. What is needed is a clear rule of law or of established practice, protecting both documents and lawyers. There are analogies. For official records, in the Public Record Office, we have an initial thirty-year rule with exceptions and extensions. In copyright, we have seventy years from the death of the author. 
Perhaps the government might give thought to adding this to the longpromised Freedom of Information Bill. Or we could have a more specific Legal Confidentiality (Termination) Act. Other professions may wish to come within it, but for present purposes I would offer something of this sort.

(1) Documents, records and all other communications or information in whatever form, which are protected by the principles of professional confidentiality between lawyer and client, shall cease to be so protected after a period of $\mathrm{X}$ years following the death of the client.

(2) The period of $X$ years shall:

(a) in the case of a client who is an individual, run from the date of death of the client, or where there are joint clients, from the date of death of the last such client; and

(b) in the case of a corporate client or partnership or other association, from the date of its winding up or other dissolution, but subject to the right of any person to seek protection of confidentiality as for an individual.

(3) Nothing in this Act shall affect:

(a) the application of legal professional privilege; (b) the right of any client or other person so entitled to make voluntary disclosure of confidential matters or to authorise any other person or body to do so;

(c) the confidentiality of any governmental or official information or communication;

(d) the confidentiality of any communication by or to any member of the Royal Family;

(e) the right of any person or body representing the interest of a former client after the said period of $\mathrm{X}$ years to apply to the court for an order to maintain confidentiality or to restrict disclosure in whole or part; but the court in deciding such application shall have regard to any public or historic interest in favour of disclosure.

(4) It shall be lawful for confidential documents and other records to which this Act applies to be deposited in an approved archive before the expiry of the period of $\mathrm{X}$ years provided that:

(a) where such deposit is made by the lawyers, it shall be expressly subject to the continuance of the confidentiality for the remainder of the period; (b) where such deposit is made by a client or by a person representing the interest of a client, it may be made subject to conditions affording restricted access as may be expressly attached to the deposit;

and the authority responsible for the archive shall from then to the end of the period maintain the confidentiality accordingly.

(5) Nothing in this Act shall operate to create confidentiality for any matter which was not protected by professional confidentiality before the passing of this Act.

(6) This Act shall come into force on [date] and shall apply retrospectively so as to release from protection any documents, communications or other information to which confidentiality previously applied if on that date the said period has already expired, but subject to this Act. (1)

\section{Victor Tunkel}

Senior Lecturer in Law, Queen Mary \& Westfield College, London University; Secretary, Selden Society; V.Tunkel@qmw.ac.uk

The author would like to thank Professor Richard C Wydick of the University of California for his help with US sources.

\section{World Trade Regulation Manual}

\section{Your subscription includes} CD ROM

- Four updates per annum

LOOSE-LEAF

- Single volume

- Four updates per annum

NEWSLETTER

- Trade Regulation Newsletter - Monthly issues

\section{SPECIAL OFFER!} Launch Price £264

Save $£ 70$ on orders received before 21 May 1999

Normal Price $£ 334.50$

An expert analysis of the World Trade Organisation regime and how it may be used to overcome barriers to international trade. As a unique feature, the regime is linked to a series of reports on actual and potential barriers to trade in 25 key trading partners.

\section{Law of World Trade \\ Organisation}

- International Regulatory Framework

- Customs Procedures

- Non-Tariff Barriers

- Investment

- Unfair Trade Practices

- Services

- Intellectual Property

- Dispute Resolution

- Leading Cases

\section{Country-by-Country} analysis of Barriers to Trade and Investment

\section{Countries covered include} Argentina; Australia; Brazil; Bulgaria; Canada; Chile; China; Egypt; EU; Hungary; India; Indonesia; Japan; Korea; Malaysia; Mexico; Paraguay; Philippines; Poland; Russia; Singapore; South Africa; Taiwan; Thailand; US 